International Review of Research in Open and Distributed Learning Volume 18, Number 1

February - 2017

\title{
Using Social Learning Networks (SLNs) in Higher Education: Edmodo Through the Lenses of Academics
}

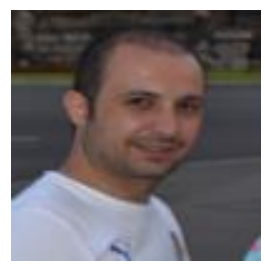

Gürhan Durak

Balıkesir University, Turkey

\begin{abstract}
With its total number of users (around 62 million) throughout the world, it is important to determine the views of academics who use Edmodo (the leading SLN. In this respect in the first part of this two-part research, the purpose was to examine academics' $(n=50)$ use of technology and social networks. As for the purpose of the second part, it was to determine the views of 12 academics-selected from the academics participating in the first part-who had experience in Edmodo about the basic features of Edmodo and about its use in education. In the study carried out with the mixed method, the qualitative and quantitative data were collected with an online questionnaire. The findings obtained were interpreted within the framework of cooperative learning and the theories of "Diffusion of Innovations" and "Uses and Gratifications," and the related themes were formed. As a result, the academics with experience in Edmodo reported their views about the benefits of use of the Edmodo in education. Regarding the differences between Edmodo and social networks, the results suggested that the former was used completely for educational purposes and that it did not involve any unnecessary components.
\end{abstract}

Keywords: distance education, online learning, social network sites, social learning networks, improving classroom teaching, interactive learning environments, learning communities

\section{Using Social Learning Networks (SLNs) in Higher Education: Edmodo Through the Lenses of Academics}

Social Networking Sites (SNS) like Facebook, MySpace, Cyworld and Bebo, which allow users to build communities and communicate and collaborate with each other, came out one after another and attracted the attentions of millions of people (Balcikanli, 2010; Baruah, 2012; Boyd \& Ellison, 2007; Cheung, Chiu, 
\& Lee, 2011; Haytko \& Parker, 2012; Lenhart \& Madden, 2007; Mazman \& Usluel, 2011; Yu, Tian, Vogel, \& Chi-Wai Kwok, 2010). Nowadays, students meet, communicate (Boyd \& Ellison, 2007; Cheung et al., 2011; Pempek, Yermolayeva, \& Calvert, 2009; Quan-Haase \& Young, 2010; Shier, 2005; Wodzicki, Schwämmlein, \& Moskaliuk, 2012; Yu et al., 2010), and build communities over SNS (Gunawardena et al., 2009; Shier, 2005). In this context, educational potential of SNS cannot be ignored considering that students take part in discussions and group activities voluntarily in SNS everyday (Bosch, 2009; Kabilan, Ahmad, \& Abidin, 2010; Odabasi et al., 2012; Selwyn, 2009; Tonta, 2009). Therefore, SNS attracted many educators' attention, and they started to try to figure out how SNS can be used in educational environments to assist their teaching (Schwartz, 2009).

There are a number of studies showing that SNS can be used successfully as a learning environment (AlRahmi \& Othman, 2013; Ekici \& Kiyici, 2012; Forkosh-Baruch \& Hershkovitz, 2012; Grosseck, Bran, \& Tiru, 2011; Hung \& Yuen, 2010; Junco, Heiberger, \& Loken, 2011; Kabilan et al., 2010; Lawson, Kleinholz, \& Bodle, 2011; Mazer, Murphy, \& Simonds, 2007, 2009; Wodzicki et al., 2012). Besides, there are also some disadvantages of use of SNS in education according to the related literature (Karpinski \& Duberstein, 2009; Rouis, Limayem, \& Salehi-sangari, 2011; Wang, Chen, \& Liang, 2011). In SNS, teachers and students are friends with each other. This situation could cause role conflicts and weaken the authority of the teacher (Warner \& Esposito, 2009). In addition, in some studies, a negative correlation was found between the frequency of SNS use and the grade point average (GPA) of students (Cohen, 2011; Junco, 2012; Kirschner \& Karpinski, 2010; O’Brien, 2011). In other words, if students use SNS more frequently, their GPAs tend to be lower. In another study, it was found out that students didn't perceive SNS as a useful tool; that they didn't want to connect with teachers over SNS because of privacy concerns; and that they didn't want SNS to be integrated into learning environments (Cohen, 2011).

The main purpose of SNS is not the field of education, and they lack some useful tools like library, quiz, assignment capacities, and so on, which are the main components of learning management systems (LMS) like Moodle and Blackboard. Moreover, there could also be lots of inappropriate contents in SNS because they are for general use. Because of the wide acceptance of SNS, educational web sites like Edmodo, Ning, and ValuePulse have emerged, which function pretty much like SNS. This kind of sites can be called Social Learning Network (SLN) (Al-kathiri, 2015; Balasubramanian, Jaykumar, \& Fukey, 2014; Bicen, 2015; Trust, 2012). SLN can give students and teachers a chance of using social networking tools by getting rid of inappropriate content and minimizing privacy and security concerns (Brady et al., 2010). SLN is designed specifically for educational environments and includes the main components of LMS like library, quiz, assignment and other functions.

The present study primarily focuses on the basic features of the leading SLN, Edmodo, and provides information about how teachers would use it. In addition, the study also tries to reveal the differences between SLN, SNS, and LMS. After referring to the theoretical foundations of the study, the academics with previous experience in Edmodo were asked for their views about their use of technology and social networks. 


\section{Edmodo}

Edmodo is an application regarding the use of SNS in education. Today, Edmodo has reached more than 62 million users in 190 countries in its fifth year (Edmodo, 2015). Among the reasons why Edmodo has become so widespread is the fact that it is totally free of charge; that it allows easy membership and provides multi-language support; that it includes a number of features expected from SNS besides its educational features; that it has a design similar to SNS in terms of use; and that students, teachers and parents can easily register with the system (Çankaya et al., 2013). Edmodo allows using the power of social media in the educational environment. For teachers and learners, it creates a safe environment in many respects such as cooperation, feedback, customized learning, and so on. It provides learners with independence of time and place, and it also helps control students and allows them to share their knowledge and ideas thanks to its related features (Edmodo, 2015).

Edmodo makes the educational environment accessible both for teachers and learners, and also for parents from any place at any time. The process starts with the teacher opening a course over the system. It is then made ready when learners enter their course code. Learners can carry out the tasks they have been assigned and also interact with their teacher in many ways using the application's basic features. Edmodo can be used in education in two ways: (a) executing the whole course online via Edmodo, and (b) using Edmodo to support a course taught on face-to-face basis (Durak et al., 2014).

Edmodo could be said to provide an alternative educational environment to LMS and SNS. In other words, if Edmodo has been favoured to execute a course, then there will be no need to use LMS and SNS. Edmodo provides such opportunities offered by SNS as allowing free sharing and acting as a source of news; in addition, it also includes such features found in LMS as a course planning tool, and homework, examination, and questionnaire applications. To put it another way, Edmodo can be said to cover most of the basic features of LMS and to be similar to SNS in terms of structure and functioning.

In this context, Edmodo has attracted educators' attention, and quite a large number of educators have started to use it in their courses. As a consequence, researchers have started to investigate Edmodo in different ways. In a study by Sanders (2012), the effects of Edmodo on students' engagement and their taking responsibility of their own learning were investigated with 42 high school students in a chemistry course. It was found that Edmodo can assist students effectively regarding engagement and taking responsibility of learning if certain features of Edmodo are used (Sanders, 2012).

Only one experimental study was found that investigates the academic performance of students using Edmodo collaboratively. In the study, it was found that in biology courses, learners using Edmodo had higher achievement scores than the traditional learners (Nee, 2014).

\section{Theoretical Framework}

In this research, both Uses and Gratifications Theory (UGT) and Diffusions of Innovations Theory (DIT) were taken into account. In addition, the study was supported with the cooperative learning theory. In related literature, studies used these theories as the basis of research on communication, media and new technologies. 
McQuail and Windahl (1993) stated that in UGT perspective researchers should try to look for solution to the questions of "Why do people use media?" and "What do they use them for?" instead of the question of "How does media affect people?" Within the UGT perspective, it is also possible to explain why people use new technologies like SLN and what they use them for (Durak, 2013).

One study examined why 12-14 year olds use SNS within the UGT perspective in Ireland. The results obtained in the study demonstrated that teenagers see themselves as regular Internet users and they use SNS mostly for communication with others. Besides, the main factors of SNS use were found to be communication, making friends, developing and managing identity, fun, escaping from realities, moving away from nuisances, information seeking, and interacting with the opposite sex (Dunne, Lawlor, \& Rowley, 2010).

Another study examined university students' purposes of Internet use, SNS, and Edmodo from the UGT perspective. For this purpose, face-to-face semi-structured interviews were held with 15 students, and a focus-group interview was held with seven students. As a result, it was revealed that the students liked such features of Edmodo as assignment, quiz, poll, announcement/sharing, and contributions of Edmodo to educational environments (Çankaya et al., 2013).

DIT was suggested by Rogers (2003) and made up of four main components: innovation, communication channels, time, and social system. Innovation can be an idea, an application, or an object that is considered to be new by the individual or organization. Innovation does not have to be a concept or design that nobody knows. If the individual or organization has not used it yet, it can then be regarded as an innovation (Berger, 2005). From a theoretical point of view, innovation can be defined as a new product, technology, point of view, or solution to a problem for individuals or organizations (Demir, 2006). Rogers (1995) pointed out that according to the model, the process of deciding on the innovation included five phases. These phases were information, convincing, decision, application, and approval. In the phase of information, the person receives information about innovation and its benefits. In the phase of convincing, the person considers the negative and positive aspects of this innovation and shapes his or her attitude accordingly. In the phase of decision, the person accepts or refuses the innovation. The phase of application occurs if the person accepts. As for the phase of approval, the person confirms and strengthens the decision related to fitness (Orr, 2003). In this research, Edmodo is regarded as an innovation for academics because they had not used it prior to this study.

Another concept that the study was based on is cooperative learning. The basis of this concept requires students to work for a common purpose in small groups. The purpose here is to allow students learn by helping each other (Jacobsen, Eggen, \& Kauchak, 2002). The method of cooperative learning helps students become individuals who think, produce, and share their productions with others (Tarim \& Akdeniz, 2003). Social networks provide students in different places with the opportunity for social and active learning and support cooperative learning (Ajjan \& Hartshorne, 2008; Özdaml \& Uzunboylu, 2008). Johnson and Johnson (2004), in their study, reported that success increases when online learning environments are supported with cooperative learning. In addition, the benefits of education via social 
networks are thought to be a result of interaction and sharing between students (Inaba \& Mizoguchi, 2004; Mora-Soto, Sanchez, Medina, \& Dominguez, 2009; Tinmaz, 2013).

In literature, there is limited research on SLN use by students (Brady et al., 2010; Bynum, 2011), and there is no study conducted to examine the use of SLN by academics from the UGT perspective. Regarding the use of SNS and SLN, which provide an online learning platform, it is important to reveal the views of academics who are expert in different fields and to determine for what purposes they use these platforms. The purpose of this study is to determine academics' use of technology and social networks and to ask for the views of academics with experience in Edmodo about the basic features of Edmodo and about its use in education.

\section{Method}

This part presents the research model, data collection tools, participants of the study, data analysis, validity and reliability studies, and the application stage of the study. The research stage is shown in Figure 1.

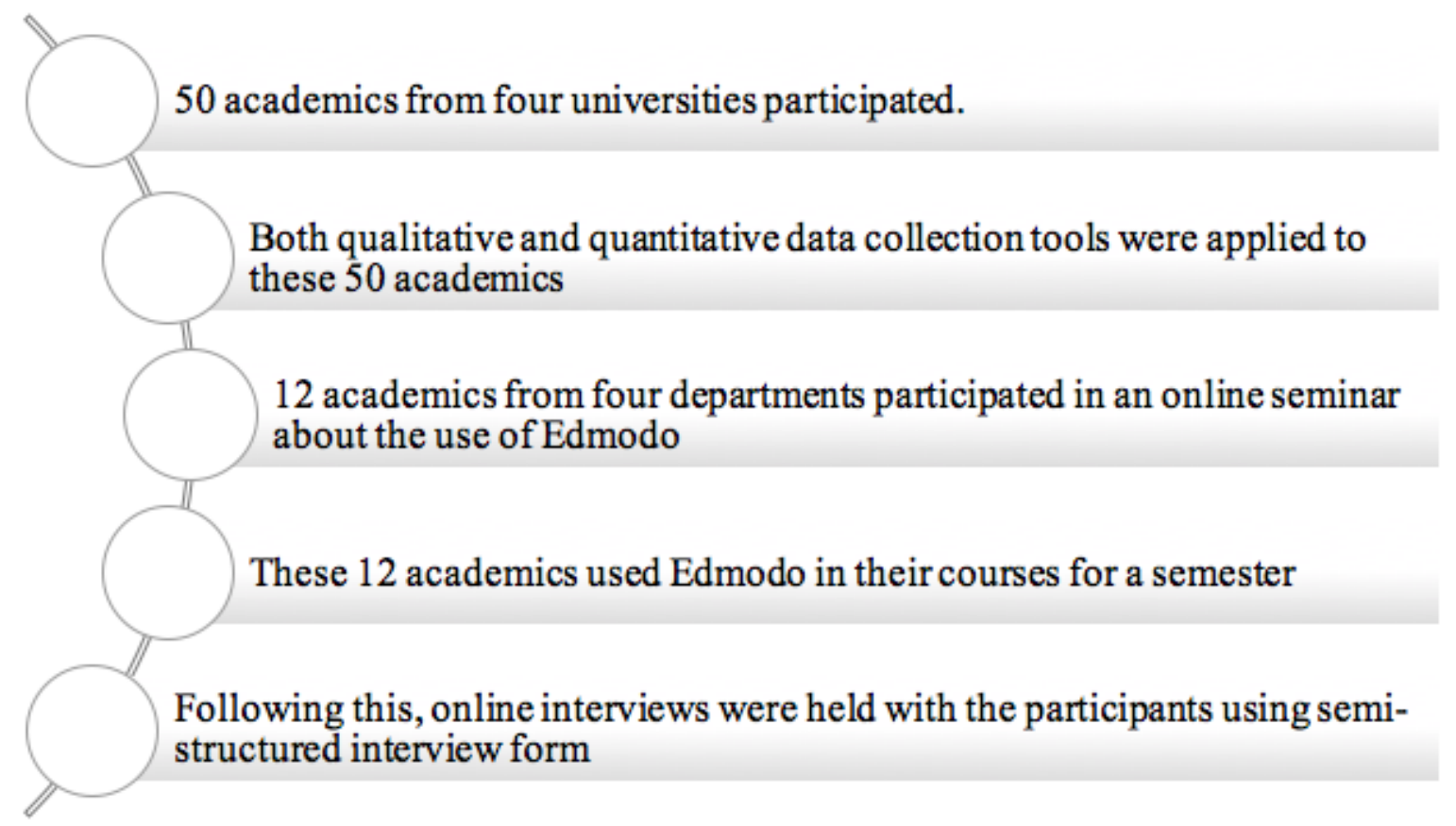

Figure 1. The research stage.

\section{Research Model}

This study's research model is mixed method. Using both quantitative and qualitative methods allowed use of the advantages of both methods and for more detailed data to be collected. According to Creswell (2012), mixed methods involve collecting, analyzing, and interpreting qualitative and quantitative data in relation to basic phenomena. 
Regarding the quantitative part of the study, mathematical data were collected to determine the academics' use of technology and social networks. As for the qualitative part, the views of a specific group of participants selected among the academics who had experience in Edmodo were determined.

When the related literature is examined, it is seen that there are a number of classifications related to mixed methods. A common typology developed for mixed methods has three dimensions: (1) Level of mixing (partially mixed versus fully mixed), (2) Time orientation (concurrent versus sequential), and (3) emphasis of approaches (equal status versus dominant status) (Johnson \& Onwuegbuzie, 2004). The present study, depending on the typology mentioned above, can be regarded as mixed method research being sequential in terms of time (quantitative-qualitative) and qualitative in terms of status.

In the study, particularly the following items were emphasized about the academics' use of technology, Edmodo and SNS.

- Academics' purposes of technology use in their courses,

- Frequency and purposes of SNS use,

- Advantages and disadvantages of SNS,

- Comparison of Edmodo and SNS,

- Comparison of Edmodo-supported courses and traditional face-to-face courses,

- Academics' views about Edmodo as an innovation in educational environments.

\section{Data Collection Tools}

Within the scope of the first part of the study, the quantitative data and some of the qualitative data were collected via a data collection tool applied via the web. The qualitative data collected in the second part of the study were gathered via web conference with the help of a semi-structured interview form developed by the researcher. According to Karasar (2005), structured interviews include questions directed via a previously-prepared form and allows determining in detail what types of questions to ask, how to direct the questions, and what data to collect. While preparing the interview questions, theories constituting the basis of the study and theoretical information obtained via the review of the related literature were taken into account. This form was then examined by experts in the fields of educational technology and measured and finalized as a result of the feedback they provided. The finalized interview form was also examined by three research assistants for readability and appropriateness, and their positive feedback made it possible to use the form in the study.

\section{Participants}

The participants in the study were determined in the following way: In the first part, 50 academics from four universities ( 28 male, 22 female) were reached, and the prepared data collection tool was applied to these academics. In the second part, among these 50 academics, a total of 12 academics from four fields of 
expertise were determined. These 12 academics were invited to use Edmodo. Following this, individual interviews were held with the academics. The fields of expertise listed below were formed to group the participants. The purpose here is to achieve data triangulation. Simple sampling is used in the first part, and 50 participants were reached. In the second part, among these participants, a total of 12 participants were determined with stratified sampling method in four groups with three members in each.

Table 1

Participants and Their Fields of Expertise

\begin{tabular}{clc}
\hline Group Code & Field of Expertise & $\begin{array}{c}\text { Number of } \\
\text { Participants }\end{array}$ \\
\hline 1 & Computer Education and Instructional Technologies & 24 \\
2 & Distance Education & 6 \\
3 & Communication & 5 \\
4 & Other Departments (Within Education Faculty) & 15 \\
\hline
\end{tabular}

\section{Data Analysis}

The data collection tool developed for the first part of the study was delivered to the participants via the web, and their responses were received online via Google forms. The participants' responses were analyzed descriptively with SPSS data analysis software. Following this, the necessary tables were formed.

In the second part of the study, the interview form was transformed into a questionnaire made up of open-ended questions and applied to the participants via online conference (Skype). The interviews lasted approximately 10 to 20 minutes. In this questionnaire, the participants were informed in detail about the method and purpose of the study. Following this, parallel to the coding draft prepared in advance, the questions, the participants, and their responses to the questions were transferred into tables.

After this, two more academics accompanied the researcher. First of all, the academics' responses to the questions were examined one by one, and each researcher formed his or her own interview coding key. The coding keys formed by the researchers were examined for consistency by the researchers and a field expert. When consistency was thought to be achieved, the data were divided into themes within the scope of the theoretical basis of the study. In addition, in order to reflect the academics' views, direct quotations were included.

According to Ylldırım and Şimşek (2008), in the process of data analysis in qualitative studies, there are three basic phases: description, analysis, and interpretation. In the description phase, the views of individuals who have been interviewed are determined. In the analysis phase, the relationships between the data and the themes obtained via the data are established. In the last phase, the interpretation phase, the findings obtained are interpreted within the context of the study.

\section{Validity and Reliability}

In order to achieve validity of the study, no question about their identities was directed to the academics via the interview form. Also, the participants were informed that their views would be used only for 
academic purposes and that their names will be confidential before the interviews. In this way, it was thought that they could express their opinions freely.

In order to achieve the reliability of the study, the findings obtained were presented without making any related personal comments. The data obtained in the study were examined by the researchers included in the study and by a faculty member experienced in qualitative research. In addition, the academics' responses were stored in a safe place to allow other researchers to access them on demand.

\section{Application Process}

In the quantitative part of the study, 50 academics from four universities were reached and research data were collected from these academics with the help of an online data collection tool. Following this, stratified sampling method was used, and the academics were divided into four groups with respect to their fields of expertise: a) Distance Education, b) Computer Education and Instructional Technologies, c) Communication, and d) Other Departments. With this grouping, the purpose was to have different views about educational social networks, which constitute a product of information and communication technologies. In the study, 12 participants determined for the qualitative part of the study were provided with an online seminar regarding the use of Edmodo. In this seminar, the participants were given applied training on registering to Edmodo, opening a course and using all other tools. The participants were asked to have an instructor's account via the website of. Also, the participants used Edmodo in their lessons with their students for four to five weeks. Following this, online interviews were held with the participants with the help of the semi-structured interview form.

\section{Findings}

The quantitative data collected from the academics revealed descriptive statistical results. Also, the coding was done and in the light of data collected via qualitative interviews, themes formed. The findings obtained were interpreted within the framework of cooperative learning with the theories of "Diffusion of Innovations" and "Uses and Gratifications." As a result, the following themes were determined: (a) Use of the Internet and SNS, (b) educational use of SNS, and (c) use and spread of Edmodo. For the first and second themes, all 50 participants were taken into account. For the third theme, a total of 12 participants from four fields of expertise who had experience in Edmodo were taken into consideration.

\section{General Use of the Internet and SNS}

Participants were asked about their use of technological devices, their Internet usage frequencies, and the educational technologies that they benefitted from. Findings were reduced into themes, and their frequencies are given in Table 2. 
Table 2

Findings Regarding General Use of the Internet and SNS

\begin{tabular}{lc}
\hline Themes & Frequency (f) \\
\hline *Frequency of Internet use & 2 \\
Low level of use & 19 \\
Average level of use & 29 \\
High level of use & \\
Technological devices they own & 50 \\
Computer & 48 \\
Smart phone & 35 \\
Tablet computer & \\
Technologies used in Education & 46 \\
Presentation software & 30 \\
Video software & 28 \\
SNS & 20 \\
Internet applications & 20 \\
E-mail & 18 \\
LMS & 3 \\
Interactive whiteboard & 2 \\
SLN (Social Learning Network) & 2 \\
\hline
\end{tabular}

Note. Determining the frequency of Internet use is taken into consideration by the data of Global Digital statistics We Are Social (2014).

It was found out that most of the participants used the Internet intensively in their daily life. In addition, all the academics had a computer, and almost all of them had a smart phone.

The academics were asked about the technologies they used in their courses. It was revealed that almost all of them used presentation software. Alongside the presentation software, they also made use of tools like video programs, SNS, e-mail, and Internet applications in their courses. Some participants stated that they used LMS, and some used interactive whiteboard and SLN. Participant 1 expressed her thoughts as follows:

Because of our work, we must use the Internet intensively. Even at home we continue to use the Internet either for personal use or for the courses we teach. I generally use presentation software in classes, and sometimes I have students watch a video about the topic I teach.

Participant 9 expressed her thoughts about the same issue as follows:

I use the Internet both at home and at work. I use it to search sources about the course and to assign homework for students. I show presentations in classes. In addition, I use mail groups to share materials and to communicate with students in my classes. Sometimes I also use the interactive whiteboard in the classroom. 


\section{General Use and Educational Use of SNS}

The findings and frequencies regarding the participants' use of SNS, intended use of SNS, opinions about disadvantages of SNS, opinions about advantages of SNS, and their opinions about the benefits of SNS in education are presented in Table 3 .

Table 3

Findings Regarding General Use and Educational use of SNS

\begin{tabular}{lc}
\hline Themes & Frequency (f) \\
\hline *Frequency of use of SNS & 6 \\
Low level of use & 18 \\
Average level of use & 26 \\
High level of use & 46 \\
Intended use of SNS & 36 \\
Communication & 27 \\
Following news \& announcements & 33 \\
Sharing & 32 \\
Fun & \\
Monitoring activities of friends and groups & 39 \\
Opinions about Disadvantages of SNS & 14 \\
Addiction & 41 \\
Violation of privacy & 44 \\
Waste of time & 15 \\
Information pollution & 36 \\
Asocial personality & 29 \\
Unnecessary sharing & 16 \\
Being an uncontrolled environment & \\
Inappropriate adds and attention distraction & 43 \\
Easy communication & 35 \\
Following news (Current events) & 28 \\
Massive sharing and awareness raising & 30 \\
Fun & 7 \\
Educational use as a support material & 33 \\
Curiosity and willingness to share & 4 \\
Providing collaborative work & \\
Sharing course materials & 24 \\
Communication with students & 37 \\
Making announcements about assignments, surveys and so on. & 18 \\
To provide an interactive learning environment & 7 \\
\hline
\end{tabular}

Note. Determining the frequency of use of SNS is taken into consideration by the data of Global Digital statistics We Are Social (2014).

It could be stated that the academics used social networks intensively. The responses revealed that almost all the academics (48) had a Facebook account. Facebook was followed by Twitter (35) and Google+ (23). Also used were LinkedIn (18), Instagram (14), Foursquare (7), Flickr (2) and ResearchGate (8). The 
academics were asked how long they had been using social networks, and the results demonstrated that most of them had used social networks for seven years or longer. When the academics were asked for what purposes they used them, it was found that almost all the participants used social networks for communication (46), followed by news and announcements (36) and friends and entertainment (33). Other prominent purposes were following group activities (29) and sharing (27). About this issue, Participant 4 expressed their thoughts as follows:

Social networks are now a part of our life. Every day, I check the news, activities, and sharing of my friends on social networking sites. When I get bored, I sign in, watch the videos shared and play online games over SNS. I also use SNS for communication.

Participant 6 expressed their thoughts as follows:

I have a few SNS accounts. But I mostly use Facebook. Almost all of my friends and acquaintances are on Facebook. I can chat, read the texts shared, and see the pictures uploaded. Especially when I am bored, I also watch videos shared by my friends. I [have] played some games on Facebook for a long time. I still play [from] time to time.

The participants mentioned similarly about the advantages of SNS. The feature of easy establishment of communication (46) was reported by most of the academics, and this feature was followed by learning about up-to-date events (35), curiosity and willingness to share (33), entertainment (30), sharing with larger populations and raising awareness (28), and using social networks to support education (7). In relation to this, Participant 19 reported that;

All the things mentioned regarding the purpose of use of social networks can be regarded as positive aspects. People can organize various activities rapidly with the help of these environments. These environments are now transformed into environments that people can use to transmit their ideas to higher authorities (TTs in Twitter). This is really very important.

On the other hand, regarding the disadvantages of SNS, the academics mostly mentioned such features of social networks as information pollution (44), waste of time (41), and addiction (39). Next were uncontrolled environment (29), inappropriate advertisements and distraction of attention (16), unsociability (15), and intervention in private life (14). In relation to the themes of information pollution, waste of time and addiction, Participant 16 stated that;

Though not true for all people, there is a risk of addiction. It could lead to waste of great time. You get exposed to a larger amount of necessary or unnecessary information, and you have to cope with such bombardment of information. It is necessary to filter the unnecessary information.

In relation to the same point, participant 8 reported that: 
I think I use SNS at addiction level. When I power on my computer, I first check my Facebook account. There are online games I play on Facebook. Sometimes I realize that I have lost too much time.

Regarding the theme of inappropriate advertisements and distraction of attention, participant 24 reported that:

Social networks are now indispensable for people. I usually find myself using Facebook, and sometimes I use it just to make announcements about a project for my students. However, I suddenly find out that I am surfing somewhere else. Then, I really feel sorry to [have wasted] my time.

Most of the participants stated that violation of privacy could be easy over SNS. In addition, the participants also mentioned that it is an uncontrolled environment. Regarding this, Participant 19 reported that:

I think social networks are favorable in a lot of ways. But sometimes they can be a pain in the neck. For instance, everyone can learn about an event regarding my family or relatives immediately. People can share their ideas on others' walls without consent and respect. A lot of unqualified videos and writings shared by people can cause information pollution.

In addition, regarding the same point, Participant 7 stated that:

Because there is a high probability of incorrect information and because it is an uncontrolled environment, there could be more events of violence and harassment than in real life.

Participant 2 indicated that social networks could reduce dialogues between people, saying:

People are always on Facebook and they manage everything there like saying 'hi' and writing to each other. This situation may cause virtuality in human behavior and thus suppress the real faceto-face human sociability.

The participants were also asked about how they made use of SNS in their courses. Most of them stated that they used SNS primarily to communicate with students (37). The participants also reported that they used SNS to share course materials (24), to make announcements about assignments and surveys (18), and create an interactive learning environment (7). In relation to this, Participant 3 stated that:

I don't give a lesson directly on a social network. However, I make use of social networks to communicate with my students. Especially, I use social networks to make announcements and to give homework.

Participant 2 expressed their thoughts as follows: 
For example, when I want to change the date of the class I write this on Facebook to inform the students. They are always on Facebook, so they see the notification just in time and inform other students. In addition, I share presentations and PDFs on Facebook for students, so they come to the class prepared.

Regarding the theme of creating an interactive learning environment, Participant 4 reported that:

In the previous academic term, I gave one of my courses via Facebook because I wanted my students to interact with each other and with me so that they can achieve more effective learning. I got positive results except for the attention-distracting features of Facebook.

\section{Use and Spread of Edmodo}

Within the scope of this main theme, only 12 participants' views were determined. The findings and frequencies regarding the participants' experience and views of Edmodo and their opinions about making Edmodo widespread can be seen in Table 4. (The participants were coded based on their fields of expertise. For example, Participant_Expertise Field Code_Order).

Table 4

Findings Regarding Use and Spread of Edmodo

\begin{tabular}{lc}
\hline Themes & Frequency (f) \\
\hline Benefits & 12 \\
Organization and discipline in learning & 10 \\
Saving time (assignments, communication, sharing and so on) & 9 \\
Feedback (timely and systematic) & 8 \\
Saving all the process of course & 8 \\
Communication (Free, timely and controlled) & 11 \\
Differences from SNS & 8 \\
Education-oriented & 11 \\
Including tools of LMS like quiz, assignment and so on. & 10 \\
Involving no useless information and features like ads, chat, sharing. & \\
Including little or no distractive features & 12 \\
Making Edmodo widespread & 6 \\
It can be used as supplementary to face-to-face courses & 12 \\
It can be used as a primary educational environment for a course & \\
I plan to use it in future & \\
\hline
\end{tabular}

The participants were asked for their opinions about the benefits of Edmodo, differences of Edmodo from SNS and making Edmodo widespread. Regarding the theme of the benefits of Edmodo, the factors of teachers' control and discipline in learning (12) and saving time (10) come into prominence. Participant 3_2 expressed their thoughts as follows: 
With this system, we can give homework easily. Similarly, it is also very easy to collect students' homework. So Edmodo reduces the time to collect students' homework. It also makes it easy to communicate with students.

Participant 4_1 expressed their thoughts about the same issue as follows:

Edmodo's feature of giving and collecting homework is very useful. It gives the teacher full control. With this system, students' responsibilities are clear. Normally I used to collect homework as papers and it was difficult to control who handed in and who did not.

Other factors about the benefits of Edmodo were found as feedback (timely and systematic), communication (free, timely, and controlled), and saving all the process of the course. Participant 1_3 expressed their thoughts as follows:

It is easy to assign and collect homework on Edmodo. It is possible to give immediate feedback on students' homework. Students can see the scores I assign to their homework immediately after I grade them. At the same time, we can inform students about their incorrect answers.

In addition, regarding the themes of taking control and recording the lesson, Participant 2_1 reported that:

It is a very good feature that Edmodo saves all the process of the course. Which student gets what score from which homework and exams? What did I write as a comment? How much did students share? And I can look for information backwards when I need. Besides, this system allows us to work with students.

Most of the academics stated that Edmodo was education-oriented and included such tools of LMS as quiz, assignment submission, and so on, unlike SNS. About this issue, almost all the participants reported their views about the features of Edmodo differed from other social networks, saying that Edmodo was used totally for educational purposes (11) and that Edmodo did not include any unnecessary features found in social networks (11). Regarding this, Participant 2_2 reported that:

The first thing to say when comparing Edmodo with SNS is that SNS is a tool for general purposes, while Edmodo is appropriate for educational purposes.

In relation to the theme of lacking unnecessary features, Participant 4_2 stated that:

Facebook is a commercial site. On Facebook, there are a lot of advertisements and applications. Besides, people can communicate and share with their friends in any way they want. In this situation, using Facebook in courses may not be reliable.

In addition to the two sub-themes above, the participants stated that Edmodo did not have any attentiondistracting features (10) and that it included the features of learning management systems (8). Regarding this, Participant 1_3 stated that: 
Edmodo has almost all the tools that LMS has. In addition, social networking capability is also included in Edmodo. So I find Edmodo very successful.

Also, in relation to the same point, Participant 3_3 reported that:

We can use Facebook in our courses. However I don't know whether we can draw students' attention to the course. Facebook is a very large network. It is almost impossible to control students on Facebook. On the other hand, on Edmodo, we can control students' activities.

In the study, lastly, the academics who experienced Edmodo were asked whether they would use Edmodo in their future lessons and, if so, in what way they would use it. All the academics stated that they would go on using Edmodo in their future lessons. Moreover, all the academics reported that Edmodo should be used in a way to support traditional teaching (12), while some of them stated that lessons could be given completely via Edmodo (6). Regarding this, Participant 4_3 stated that:

There are a lot of features on Edmodo. Our students are already accustomed to the Internet. In this situation, I think we can benefit from Edmodo as a supplementary tool to traditional courses given in the classrooms. It may be easy to do this with the tools Edmodo has.

From a different perspective, Participant 1_1 expressed her thoughts as follows:

In future, I think education will be self-oriented. With the students who know their responsibilities of learning, it is possible to teach courses completely on Edmodo. It is easy to share course materials, assign homework, and make announcements on Edmodo. Students can be directed to work in groups. So they can share their work and their ideas in the groups of an Edmodo course. If quiz module were improved a little bit, everything would be performed on Edmodo.

\section{Conclusion, Discussion, and Suggestions}

In the first part of this two-part study, the purpose was to determine 50 academics' use of technology and social networks who were from different fields of expertise. The second part of the study aimed at determining the views of 12 academics-selected among these 50 academics with experience in Edmodoabout the basic features of Edmodo and its use in education. The data collected with an online data collection tool demonstrated that the academics who participated in the study used the Internet and SNS intensively. It was found that all the participants had a computer and that almost all had a smart phone. In addition, according to the findings, presentation and video software were key educational technologies that academics used in their courses. Other technologies that academics used in their courses were found to be Internet applications, e-mail, SNS, and so on. This result is consistent with other findings reported in related literature that presentation applications are still being widely used regardless of how advanced technology is (Bower, Hedberg, \& Kuswara, 2009; Kennedy, Jones, Chambers, \& Peacock, 2011). 
Furthermore, the findings are also supported with those of another study carried out with 286 instructors at a university (Kennedy et al., 2011) reporting that instructors use presentation software $(82,2 \%)$, video $(48,4 \%)$, Internet applications (11\%), and SNS $(8,5 \%)$ in instructional activities.

When the academics' frequencies of social network use were examined, it was seen that most of them used social networks intensively. Facebook was most frequently used, followed by Twitter, Google+, and LinkedIn. These findings are similar to those obtained by Ayres (2012) and Miah, Omar, \& AllisonGolding (2012). As purpose, the academics used social networks to follow their friends, group activities, and news and announcements. These purposes were followed by communication, sharing, and entertainment. In a report published by Higher Education, it was pointed out that academics mostly use social networks to communicate with their friends and to obtain information (Ayres, 2012). When viewed from this perspective, these results are consistent with the findings obtained in the present study.

When the academics' use of social networks are considered within the theories of usages and satisfactions, it is seen that such satisfactions as information seeking, entertainment, and communication with others were reported in several studies in related literature (Boyd \& Ellison, 2007; Charney \& Greenberg, 2001; Cheung et al., 2011; Dunne et al., 2010; Larose, Mastro, \& Eastin, 2001; Papacharissi \& Rubin, 2010; Pempek et al., 2009; Shier, 2005; Wodzicki et al., 2012; Yu et al., 2010).

In the study, it was also revealed that the participants used Facebook mostly and Twitter, Google+, and LinkedIn less frequently. This finding is similar to Ayres' report investigating the views of 29 academics about the SNS use in education (2012). In this report, it was stated that the most popular SNSs used by academics were Facebook (81\%), YouTube (71\%), LinkedIn (70\%), and Twitter $(70 \%)$ and that the participants reported their intended use of SNS mostly as following news and announcements and monitoring activities of friends and groups and less frequently as communication, sharing, and entertainment. In addition, the report also demonstrated that the academics preferred to use SNS mostly to obtain information and to communicate with friends.

In relation to the negative features of social networks, the academics mostly mentioned the items of causing waste of time, leading to addiction, and intervening private life, which were followed by information pollution and causing asocial personality. Parallel to these findings, other studies revealed that social networks have negative effects on addiction, waste of time, and asocial personality ("People's addiction to", 2010; Renganayar, 2010; Kuss \& Griffiths, 2011). When studies in related literature are examined, it is seen that social networks lead to negative results in relation to academic performance (Wang, Chen, \& Liang, 2011; O’Brien, 2011; Cohen, 2011; Reynol Junco, 2012). In some of these studies, it was reported that students spending too much time on social networks study less and that they are less successful in their courses (Kirschner \& Karpinski, 2010; Rouis et al., 2011). Among the positive features of social networks, communication and following the news were most prominent. In literature, studies conducted in relation to the use of social networks in education demonstrate that social networks support communication (Urista, Dong \& Day, 2009; Baker \& Oswald, 2010; Quan-Haase \& Young, 2010). Communication and following the news were followed by curiosity and willingness to share, entertainment, and sharing with larger populations. 
According to the participants of the present study, the negative aspects of SNS were addiction, violation of privacy, wasting time, information pollution, and asocial personality. In literature, it is reported that intensive use of SNS could cause poor academic performance (Kirschner \& Karpinski, 2010; Rouis et al., 2011). It is possible to link poor academic performance to addiction. If students spend a lot of time on SNS, they may not have enough time to study. As a result, it could be stated that students who use SNS at an addiction level may have lower academic performance than those who do not use SNS that much.

The participants were asked about how they made use of SNS for their courses. They stated that they used SNS to communicate with students, to make announcements about assignments and surveys, and to share course materials. Similarly, Bicen, Ozdamli, and Uzunboylu (2012) found that SNS improved communication between students and teachers and that SNS also made it easy to share course materials. In addition, Ajjan and Hartshorne (2008) showed that SNS use in education enhanced communication and interaction between students and teachers. In another study conducted with 1920 faculty members by Babson Survey Research Group (Moran, Seaman, \& Tinti-kane, 2011) regarding SNS use in education, it was revealed that $99 \%$ of them had a Facebook account; that $64 \%$ of them used SNS in their courses; and that $58 \%$ of them thought SNS supports collaborative learning. Similarly, in related literature, several studies mentioned the purposes of SNS use like communication, entertainment, and information seeking (Boyd \& Ellison, 2007; Charney \& Greenberg, 2001; Cheung et al., 2011; Dunne et al., 2010; Larose, Mastro, \& Eastin, 2001; Papacharissi \& Rubin, 2010; Pempek et al., 2009; Shier, 2005; Wodzicki et al., 2012; Yu et al., 2010).

Lastly, in the study, when the academics were asked whether they would use Edmodo in their future courses or not, all of them said they thought they would. This is supported by them opening more new course(s) on Edmodo within the scope of the study. This result can be explained with the theory of diffusion of innovations. Within the framework of this theory, the fact that the academics did not have any previous experience in SLN like Edmodo caused them to regard these applications as an innovation. Their thoughts that use of Edmodo in education would be beneficial could be said to demonstrate that they adopted innovation. Consequently, considering that the academics thought the spread of SLN like Edmodo would be beneficial both for students and for teachers and should be used to support lessons, and that they opened courses through Edmodo outside of the scope of the study, can be explained with diffusion of innovations.

Lastly, the academics' views about using Edmodo in educational settings and making Edmodo widespread were examined. The participants stated that educators can take advantage of Edmodo because it can save time for tasks like assignments, communication, sharing, and so on, because it can support organization and discipline in learning, because it is easy to give feedback to students' works with Edmodo, because it saves all the process of the course and because communication is easy, free, timely, and controlled with Edmodo. Besides, the participants thought that Edmodo differs from SNS in that Edmodo is educationoriented and includes little or no distractive features, that it does not include useless information or features like advertisements, chat, and sharing (like SNS), and that it includes useful tools of LMS like quiz and assignment. Also, all the participants wanted to use Edmodo in their course in future. Parallel to this, after the seminar, some of the academics started to use Edmodo in their courses. This situation can 
be explained by the theory of diffusions of innovations. Edmodo was an innovation for the participants because they had never used Edmodo before the seminar and because they did not know about it. It could also be stated that the participants of the present study seemed to adopt the innovations because they reported that Edmodo could be useful for them. They also seemed to support the diffusion of innovation because they thought that Edmodo could be made widespread and because they started to use it.

Most of the academics thought that Edmodo should be used as a supplementary tool to traditional faceto-face education. This finding is parallel with the findings of a doctoral dissertation thesis study carried out by Tinmaz (2011) who investigated the use of SNS in teaching and learning processes in UGT perspective. In the study, most of the participants reported that it could be more appropriate if SNS is used as a supplementary tool in educational environments. On the other hand, some of the participants of the present study stated that it could also be used as a primary educational environment if some changes were made to Edmodo. Besides, some of the participants of the present study also stated that Edmodo supports collaborative learning because it allows working in small groups and enables students to share their ideas and materials freely. This finding shows similarity with the related literature that online learning environments and SNS offer collaborative learning environments (Ajjan \& Hartshorne, 2008; Ozdamli \& Uzunboylu, 2008).

According to the results of this research and considering the advantages of Edmodo, the following recommendations were made:

- It is recommended that educators use Edmodo in their courses.

- It is recommended that school administrators encourage teachers to use Edmodo and that they give seminars to introduce Edmodo to teachers.

- It is recommended that schools administrators apply for a school-admin account for Edmodo.

- It is recommended that researchers develop an SLN attitude scale for students and use this scale in a large sample group.

- It is recommended that researchers conduct an experimental study in which students in the experimental group use Edmodo and those in the control group do not.

- It is recommended that researchers conduct an experimental study in which students in the experimental group use Edmodo and those in the control group use LMS.

- It is recommended that researchers carry out comparative studies in different fields. 


\section{References}

Ajjan, H., \& Hartshorne, R. (2008). Investigating faculty decisions to adopt Web 2.o technologies: Theory and empirical tests. The Internet and Higher Education, 11(2), 71-80. doi:10.1016/j.iheduc.2008.05.002

Al-kathiri, F. (2015). Beyond the Classroom Walls: Edmodo in Saudi Secondary School EFL Instruction, Attitudes and Challenges. English Language Teaching, 8(1), 189-204. doi:10.5539/elt.v8n1p189

Al-Rahmi, W. M., \& Othman, M. S. (2013). The impact of social media use on academic performance among university students: A pilot study. Journal Of Information Systems Research And Innovation, 4(2), 1-10.

Ayres, S. (2012). How social work academics are using social media to support student learning. York: Higher Education Academy.

Baker, L. R., \& Oswald, D. L. (2010). Shyness and online social networking services. Journal of Social \& Personal Relationships, 27(7), 873-889. doi:10.1177/0265407510375261

Balasubramanian, K., Jaykumar, V., \& Fukey, L. N. (2014). A study on "student preference towards the use of Edmodo as a learning platform to create responsible learning environment." ProcediaSocial and Behavioral Sciences, 144, 416-422. doi:10.1016/j.sbspro.2014.07.311

Balcikanli, C. (2010). The effects of social networking on pre-service english teachers' metacognitive awareness and teaching practice (Unpublished doctoral dissertation). Gazi University Institute of Educational Sciences, Ankara.

Baruah, T. D. (2012). Effectiveness of social media as a tool of communication and its potential for technology enabled connections: A micro-level study. International Journal of Scientific and Research Publications, 2(5), 1-10.

Berger, J. I. (2005). Perceived consequences of adopting the Internet into adult literacy and basic education classrooms. Adult Basic Education, 15(2), 103-121.

Bicen, H., Ozdamli, F., \& Uzunboylu, H. (2012). Online and blended learning approach on instructional multimedia development courses in teacher education. Interactive Learning Environments, 120. doi:10.1080/10494820.2012.682586

Bicen, H. (2015). The role of social learning networks in mobile assisted language learning: Edmodo as a case study. Journal of Universal Computer Science, 21(10), 1297-1306. 
Bosch, T. E. (2009). Using online social networking for teaching and learning: Facebook use at the University of Cape Town. South African Journal for Communication Theory and Research, 35(2), 185-200.

Bower, M., Hedberg, J., \& Kuswara, A. (2009). Conceptualising Web 2.0 enabled learning designs. In Same places, different spaces. Proceedings ascilite Auckland 2009 (pp. 1153-1162). Auckland, New Zealand.

Boyd, D. M., \& Ellison, N. B. (2007). Social network sites: Definition, history, and scholarship. Journal of Computer-Mediated Communication, 13(1), 210-230. doi:10.1111/j.1083-6101.2007.00393.x

Brady, K. P., Holcomb, L. B., \& Smith, B. V. (2010). The use of alternative social networking sites in higher educational settings: A case study of the e-learning benefits of Ning in education. Journal of Interactive Online Learning, 9(2), 151-170.

Bynum, S. L. (2011). Utilizing social media to increase student engagement: A study of Kern County public schools (Unpublished master's thesis). California State University Department of Public Policy and Administration, Bakersfield.

Çankaya, S., Durak, G., \& Yünkül, E. (2013). Using educational social networking sites in higher education: Edmodo through the lenses of undergraduate students. European Journal of Education Technology, 1(1), 3-23.

Charney, T., \& Greenberg, B. S. (2001). Uses and gratifications of the Internet. In C. A. Lin \& D. J. Atkin (Eds.), Communication Technology and Society: Audience Adoption and Uses of the New Media (pp. 379-407). Cresskill, NJ: Hampton.

Cheung, C. M. K., Chiu, P.-Y., \& Lee, M. K. O. (2011). Online social networks: Why do students use Facebook? Computers in Human Behavior, 27(4), 1337-1343. doi:10.1016/j.chb.2010.07.028

Cohen, A. (2011). Higher education students' perspectives of the relevance of the online social networking site Facebook to education (Unpublished doctoral dissertation). Walden University College of Social and Behavioral Sciences.

Demir, K. (2006). Rogers'in yeniligin yayilmasi teorisi ve Internetten ders kaydi [Rogers' Theory of the Diffusion of Innovations and Online Course Registration]. Egitim Yonetimi Dergisi, 12(47), 367391.

Dunne, A., Lawlor, M., \& Rowley, J. (2010). Young people's use of online social networking sites - a uses and gratifications perspective. Journal of Research in Interactive Marketing, 4(1), 46-58.

Durak, G. (2013). Programlama Dillerinin Cevrimici Ogretimi: Ogrenenlerin Tutumlarinin, Memnuniyetlerinin ve Akademik Basarilarinin Incelenmesi [The online teaching of 
programming languages: examining learner's attitudes, satisfaction and success] (Unpublished doctoral dissertation). Anadolu Universitesi Sosyal Bilimler Enstitüsü.

Durak, G., Çankaya, S., \& Yünkül, E. (2014). Using educational social networking sites in education: Edmodo. Dumlupinar University Journal of Social Sciences, 41, 309-316.

Edmodo (2015). About Edmodo. Retrieved from https://www.edmodo.com/about

Ekici, M., \& Kiyici, M. (2012). Sosyal aglarin egitim baglaminda kullanimi [Using social networks in educational context]. Usak Universitesi Sosyal Bilimler Dergisi, 5(2), 156-167.

Forkosh-Baruch, A., \& Hershkovitz, A. (2012). A case study of Israeli higher-education institutes sharing scholarly information with the community via social networks. The Internet and Higher Education, 15(1), 58-68. doi:10.1016/j.iheduc.2011.08.003

We Are Social. (2014). Global Digital Statistics 2014. Retrieved from http://etonpreneurs.com/uploads/Global\%20Social,\%20Digital\%20\&\%20Mobile\%20Statistics,\% 20Jan\%202014.pdf

Grosseck, G., Bran, R., \& Tiru, L. (2011). Dear teacher, what should I write on my wall? A case study on academic uses of Facebook. Procedia-Social and Behavioral Sciences, 15(2011), 1425-1430. doi:10.1016/j.sbspro.2011.03.306

Gunawardena, C. N., Hermans, M. B., Sanchez, D., Richmond, C., Bohley, M., \& Tuttle, R. (2009). A theoretical framework for building online communities of practice with social networking tools. Educational Media International, 46(1), 3-16. Retrieved from http://onlinelibrary.wiley.com/doi/10.1002/cbdv.200490137/abstract

Haytko, D. L., \& Parker, R. S. (2012). Social networking tools in a university setting: a student's perspective. Journal of Instructional Pedagogies, 9, 1-9.

Hung, H.-T., \& Yuen, S. C.-Y. (2010). Educational use of social networking technology in higher education. Teaching in Higher Education, 15(6), 703-714. doi:10.1080/13562517.2010.507307

Inaba, A., \& Mizoguchi, R. (2004). Learners roles and predictable educational benefits in collaborative learning: an ontological approach to support design and analysis of CSCL. In Seventh International Conference on Intelligent Tutoring Systems, (pp. 285-294). Alagoas, Brazil.

Jacobsen, D.A., Eggen, P. \& Kauchak, D. (2002). Methods for teaching (6th ed). Upper Saddle River, NJ: Merrill-Prentice Hall.

Johnson, D. W., and R. T. Johnson. (2004). Cooperation and the use of technology. In D. H. Jonassen (Ed.), Handbook of research on educational communications and technology (pp. 785-811). Mahwah, NJ: Lawrence Erlbaum. 
Johnson, B., \& Onwuegbuzie, A. (2004). Mixed methods resarch: A research paradigm whose time has come. Educational Researcher, 33(7), 14-26.

Junco, R. (2012). The relationship between frequency of Facebook use, participation in Facebook activities, and student engagement. Computers \& Education, 58(1), 162-171. doi:10.1016/j.compedu.2011.08.004

Junco, R., Heiberger, G., \& Loken, E. (2011). The effect of Twitter on college student engagement and grades. Journal of Computer Assisted Learning, 27(2), 119-132. doi:10.1111/j.13652729.2010.00387.x

Kabilan, M. K., Ahmad, N., \& Abidin, M. J. Z. (2010). Facebook: An online environment for learning of English in institutions of higher education? The Internet and Higher Education, 13(4), 179-187. doi:10.1016/j.iheduc.2010.07.003

Karasar, N. (2005). Bilimsel araştırma yöntemi: Kavramlar, ilkeler, teknikler [The scientific research method: Ceoncepts, principles, techniques] (15th ed). Ankara: Nobel Yayın Dağıtım.

Karpinski, A. C., \& Duberstein, A. (2009). A description of Facebook use and academic performance among undergraduate and graduate students. In American Educational Research Association Annual Meeting. San Diego, California.

Kennedy, G., Jones, D., Chambers, D., \& Peacock, J. (2011). Understanding the reasons academics useand don't use-endorsed and unendorsed learning technologies. In G. Williams, P. Statham, N. Brown, B. Cleland (Eds.), Changing Demands, Changing Directions. Proceedings ascilite Hobart 2011 (pp. 688-701). Hobart, Australia.

Kirschner, P. A., \& Karpinski, A. C. (2010). Facebook® and academic performance. Computers in Human Behavior, 26(6), 1237-1245. doi:10.1016/j.chb.2010.03.024

Kuss, D.J., \& Griffiths, M.D. (2011). Online social networking and addiction-A review of the psychological literature. International journal of environmental research and public health, 8(9): 3528-3552.

Larose, R., Mastro, D., \& Eastin, M. S. (2001). Understanding Internet usage: A social-cognitive approach to uses and gratifications. Social Science Computer Review, 19(4), 395-413. doi:10.1177/089443930101900401

Lawson, T. J., Kleinholz, S. A., \& Bodle, J. H. (2011). Using Facebook to connect alumni, current students, and faculty: A how-to guide. Teaching of Psychology, 38(4), 265-268. doi:10.1177/0098628311421327

Lenhart, A., \& Madden, M. (2007). Teens, privacy \& online social networks: How teens manage their online identities and personal information in the age of MySpace. Washington, D.C.: Pew 
Internet \& American Life Project. Retrieved from

http://www.pewinternet.org/ /media//Files/Reports/2007/PIP_Teens_Privacy_SNS Report Final.pdf.pdf

Mazer, J. P., Murphy, R. E., \& Simonds, C. J. (2007). I'll see you on "Facebook": The effects of computermediated teacher self-disclosure on student motivation, affective learning, and classroom climate. Communication Education, 56(1), 1-17. doi:10.1080/03634520601009710

Mazer, J. P., Murphy, R. E., \& Simonds, C. J. (2009). The effects of teacher self-disclosure via Facebook on teacher credibility. Learning, Media and Technology, 34(2), 175-183.

doi:10.1080/17439880902923655

Mazman, S. G., \& Usluel, Y. K. (2011). Gender differences in using social networks. The Turkish Online Journal of Educational Technology, 10(2), 133-139.

McQuail, D., \& Windahl, S. (1993). Communication models for the study of mass communications (2nd ed.). London: Longman.

Miah, M., Omar, A., \& Allison-Golding, M. (2012) Effects of Social Networking on Adolescent Education. Proceedings of the Information Systems Educators Conference, 29(1927), (pp. 1-11). New Orleans Louisiana, USA: EDSIG (Education Special Interest Group of the AITP). Retrieved from www.aitp-edsig.org.

Mora-Soto, A. Sanchez-Segura, M-I., Medina-Dominguez, F., \& Amescua, A. (2009). Collaborative learning experiences using social networks. 1st International Conference on Education and New Learning Technologies, (pp. 4260-4270). Barcelona: Edulearno9. Retrieved from https://www.academia.edu/194162/Collaborative Learning Experiences Using Social Networ $\underline{\mathrm{ks}}$

Moran, M., Seaman, J., \& Tinti-kane, H. (2011). Teaching, Learning , and Sharing: How Today's Higher Education Faculty Use Social Media. Boston: Pearson Learning Solutions.

Nee, C. K. (2014). The Effect of Educational Networking on Students' Performance in Biology. International Journal on Integrating Technology in Education, 3(1), 21-41. doi:10.5121/ijite.2014.3102

O'Brien, S. J. (2011). Facebook and other Internet use and the academic performance of college students (Unpublished doctoral dissertation). The Temple University Graduate School.

Odabasi, H. F., Misirli, O., Gunuc, S., Timar, Z. S., Ersoy, M., Som, S., Erol, O. (2012). Egitim icin yeni bir ortam: Twitter [A New Media for Education: Twitter]. Anadolu Journal of Educational Sciences International, 2(1), 89-103. 
Orr, G. (2003). Diffusion of innovation, by Everett Rogers (1995). Retrieved from http://www.stanford.edu/class/symbsys205/Diffusion\%200f\%20Innovations.htm.

Özdamlı, F., \& Uzunboylu, H. (2008). Ogretmen adaylarinin teknoloji destekli isbirlikli ogrenme ortamina yonelik tutumları [The attitudes of preservice teachers on technology supported colloborative learning environment]. Cypriot Journal Of Educational Sciences, 5, 28-36.

Papacharissi, Z., \& Rubin, A. M. (2010). Predictors of Internet use. Journal of Broadcasting and Electronic Media, 44(2), 175-196.

Pempek, T. A., Yermolayeva, Y. A., \& Calvert, S. L. (2009). College students' social networking experiences on Facebook. Journal of Applied Developmental Psychology, 3o(3), 227-238. doi:10.1016/j.appdev.2008.12.010

People's addiction to networking sites on rise: Study. (2010, March 25). Retrieved from http://economictimes.indiatimes.com/infotech/internet/Peoples-addiction-to-networking-siteson-riseStudy/articleshow/5721998.cms

Quan-Haase, a., \& Young, a. L. (2010). Uses and Gratifications of Social Media: A Comparison of Facebook and Instant Messaging. Bulletin of Science, Technology \& Society, 30(5), 350-361. doi:10.1177/0270467610380009

Renganayar, C. (2010, August 1). Do you have facebook addiction disorder?. Retrieved from http://findarticles.com/p/news-articles/new-straitstimes/mi 8016/is 20100801/facebookaddiction-disorder/ai n54636605/

Rogers, M.E. (1995). Diffusion of innovations (4 th ed). New York: The Free Press.

Rogers, M. E. (2003). Diffusion of innovation (5th ed.). New York: The Free Press.

Rouis, S., Limayem, M., \& Salehi-sangari, E. (2011). Impact of Facebook usage on students' academic achievement: roles of self-regulation and trust. Electronic Journal of Research in Educational Psychology, 9(3), 961-994.

Sanders, K. S. (2012). An examination of the academic networking site Edmodo on student engagement and responsible learning. (Unpublished doctoral dissertation). University of South Carolina College of Education.

Schwartz, H. (2009). Facebook: The new classroom commons. The Chronicle of Higher Education, 56(6), B12-B13.

Selwyn, N. (2009). Faceworking: exploring students' education-related use of Facebook. Learning, Media and Technology, 34(2), 157-174. doi:10.1080/17439880902923622 
Shier, M. T. (2005). The way technology changes how we do what we do. New Directions for Student Services, 2005(112), 77-87. doi:10.1002/ss.186

Tarım, K., \& Akdeniz, F. (2003). Using cooperative learning in primary school math courses. Hacettepe University Journal of Education, 24, 215-223.

Tinmaz, H. (2011). Sosyal ag web sitelerinin egitimde kullanilmasi: Facebook ornegi [The use of social networking sites in education: Facebook] (Unpublished Doctoral Dissertation). Middle East Technical University Institute of Science.

Tinmaz, H. (2013). Sosyal ag web siteleri ve sosyal aglarin egitimde kullanimi [The use of social networking sites and social networks in education].In K. Cagiltay \& Y. Goktas (Eds.), Ogretim Teknolojilerinin Temelleri: Teoriler, Arastirmalar, Egilimler (pp. 615-630). Ankara: Pegem Akademi.

Tonta, Y. (2009). Dijital Yerliler, Sosyal Aglar ve Kutuphanelerin Gelecegi [Digital Natives and the future of social networks and libraries]. Turk Kutuphaneciligi, 23(4), 742-768.

Trust, T. (2012). Professional Learning Networks Designed for Teacher Learning. Journal of Digital Learning in Teacher Education, 28(4), 133-138. doi:10.1080/21532974.2012.10784693

Urista, M.A., Dong, Q., \& Day, K.D. (2009). Explaining why young adults use myspace and facebook through uses and gratifications theory. Human Communication, 12(2), 215- 229.

Wang, Q., Chen, W., \& Liang, Y. (2011). The effects of social media on college students. Johnson \& Wales University, Providence, RI. Retrieved from http://scholarsarchive.jwu.edu/mba_student/5/

Warner, B., \& Esposito, J. (2009). What's not in the syllabus: Faculty transformation, role modeling and role conflict in immersion service-learning courses. International Journal of Teaching and Learning in Higher Education, 20(3), 510-517.

Wodzicki, K., Schwämmlein, E., \& Moskaliuk, J. (2012). “Actually, I wanted to learn”: Study-related knowledge exchange on social networking sites. The Internet and Higher Education, 15(1), 9-14. doi:10.1016/j.iheduc.2011.05.008

Yıldırım, A., \& ve Şimşek, H. (2008). Sosyal bilimlerde nitel araştırma yöntemleri [Qalitative research methods in social sciences] (6th ed). Ankara: Seçkin Yayıncllı.

Yu, A. Y., Tian, S. W., Vogel, D., \& Chi-Wai Kwok, R. (2010). Can learning be virtually boosted? An investigation of online social networking impacts. Computers \& Education, 55(4), 1494-1503. doi:10.1016/j.compedu.2010.06.015 
Using Social Learning Networks (SLNs) in Higher Education: Edmodo Through the Lenses of Academics Durak

\section{Athabasca}

University

(c) 